\title{
KELAS SENTRA: PEMBELAJARAN MEMBACA, MENULIS, DAN BERHITUNG (CALISTUNG) PADA SENTRA PERSIAPAN RA AL- AZHAR KOTA LANGSA
}

\author{
Siti Habsari Pratiwi \\ IAIN Langsa \\ rastibila@gmail.com
}

\section{ABSTRAK}

RA Al- Azhar Kota Langsa menerapkan kelas sentra untuk proses pembelajarannya. Penelitian ini bertujuan untuk mengetahui bagaimana sentra persiapan menyajikan proses pembelajaran untuk mengenalkan pembelajaran membaca, menulis, dan berhitung. Penelitian ini menggunakan pendekatan kualitatif. Pengumpulan data dilakukan dengan indepth - interview, observasi dan studi dokumen. Pembelajaran membaca dimulai dengan strategi pengenalan huruf dan angka terlebih dahulu. Proses pengenalan huruf dan angka dilakukan dengan menggunakan media lagu. Pembelajaran membaca juga disajikan dengan menggunakan kartu acak. Pembelajaran menulis dilakukan dengan tahapan, merangkai huruf yang telah ditulis dengan garis putusputus, menebalkan huruf, hingga menulis tingkat lanjutan berupa menulis kata-kata sederhana. Begitu juga pembelajaran berhitung dilakukan secara bertahap. Dimulai dari pengenalan angka, pemahaman konsep dituangkan ke dalam penulisan lambang angka, kemudian pada tahap lebih lanjut anak dikenalkan dengan operasi berhitung. Seluruh aktivitas pembelajaran dilakukan dengan bantuan alat dan media yang dapat meningkatkan minat dan kreativitas siswa. Selain itu, aktivitas pembelajaran disajikan dalam bentuk permainan.

Kata kunci

kelas sentra, membaca, menulis dan berhitung.

\section{LATAR BELAKANG}

Pendidikan usia dini merupakan wahana pendidikan yang sangat fundamental dalam memberikan kerangka dasar terbentuknya atau berkembangnya dasar-dasar pengetahuan, sikap dan keterampilan pada anak 
serta keberhasilan pendidikan selanjutnya. Keberhasilan penyelenggaraan pendidikan pada lembaga pendidikan anak usia dini dapat dilakukan melalui: kelompok bermain, taman penitipan anak, satuan padu sejenis maupun taman kanak-kanak yang sangat bergantung pada sistem dan proses pendidikan yang dijalankan.

Banyak hal yang bisa meningkatkan perkembangan anak ketika ia mengalami proses belajar yang menyenangkan, salah satunya adalah perkembangan kreativitas. Mursid (2015: 4-5) mengutip pernyataan Seto Mulyadi, seorang pakar anak, kreativitas alamiah pada diri anak akan tampak dari perilaku mereka yang sering bertanya, senang menjajaki lingkungan, tertarik untuk mencoba segala sesuatu, dan memiliki daya khayal yang tinggi.

Bennet, Finn, and Cribb (1999 : 91-100) menyatakan bahwa pengembangan sejumlah pengalaman belajar untuk anak harus dilakukan melalui kegiatan bermain yang bertujuan memperkaya pengalaman anak. Pengalaman belajar yang didesain dengan baik agar kesempatan bermain tidak tersita dengan kegiatan belajarnya. Materi-materi yang disajikan harus disesuaikan dengan ranah perkembangan anak. Dengan demikian, perlu didesain proses pembelajaran dengan konsep belajar dalam bermain bagi anak PAUD.

Pembelajaran pada PAUD biasanya terdiri dari kegiatan-kegiatan yang melibatkan ranah psikomotorik dan kognitif, misalnya penguasaan keterampilan membaca. Kegiatan membaca seharusnya tidak boleh dipaksakan pada anak. Dalam Peraturan Menteri Pendidikan Nomor 58 Tahun 2009 mengelompokkan rombongan belajar peserta didik pada layanan PAUD jalur pendidikan formal dibagi menjadi kelompok A untuk usia anak 4-5 tahun dan kelompok B untuk anak usia 5-6 tahun. Kegiatan belajar pada usia ini harus bersifat menyenangkan. 
Maimunah (2009:314) menyebutkan bahwa kegiatan belajar melalui metode sosialisasi jauh lebih efektif daripada metode pemaksaan. Dengan cara ini anak mulai mengenal huruf-huruf yang membentuk nama benda tersebut. Pengenalan huruf dilakukan dimulai dari benda-benda yang paling sering ditemuinya, seperti $/ \mathrm{m} / / \mathrm{a} / / \mathrm{m} / / \mathrm{a} / ; / \mathrm{p} / / \mathrm{a} / / \mathrm{p} / / \mathrm{a} / ; / \mathrm{s} / / \mathrm{u} / / \mathrm{s} /$ $/ \mathrm{u} /$, dan lainnya. Selain meggunakan metode sosialisasi, metode lain yang dapat digunakan untuk mengenalkan keterampilan membaca pada anak adalah dengan berbantuan media permainan

Berdasarkan hasil observasi awal di RA Al-Azhar Kota Langsa, di RA ini tidak mengajarkan CALISTUNG (membaca, menulis, dan berhitung) secara khusus, namun mereka mengajarkan hafalan dengan berupa gambargambar agar siswa bisa mengingat sendiri, namun tidak dipaksa untuk bisa calistung. Salah satu kenyataan yang ada di lapangan adalah motivasi orang tua memasukkan memasukkan anaknya ke TK dengan harapan agar anaknya nanti mampu baca dan tulis, sehingga bisa diterima di SD favorit di kota Langsa. Orang tua menuntut anak untuk dapat membaca dan menulis karena takut anak tidak diterima di Sekolah Dasar yang menggunakan seleksi bagi calon murid dengan bentuk seleksi penerimaan siswa baru. RA Al Azhar merupakan RA yang lulusannya banyak diterima di SD/MI favorit di Langsa, sehingga menyekolahkan anak di tempat ini adalah salah satu pilihan terbaik.

Penginvestigasian mengenai implementasi pembelajaran materi calistung pada TK dan RA menjadi penting. Pertama, guru TK/RA sebagai aktor yang mengetahui bagaimana idealnya pembelajaran TK/RA dengan dasar bermain harus menghadapi kenyataan bahwa orang tua menghendaki anak-anaknya mengalami perkembangan kognitif dalam aspek mampu membaca, menulis, dan berhitung. Kedua, orang tua memiliki impian bahwa anak-anak akan memiliki kemampuan baca, tulis, dan berhitung dengan baik 
di tingkat pendidikan usia dini agar bisa memasuki SD favorit. Meskipun, mereka menyadari bahwa TK/RA adalah PAUD yang proses pembelajarannya berorientasi pada kegiatan bermain. Ketiga, penelitian ini akan meneliti bagaimana pembelajaran calistung diterapkan di Kelas Sentra Persiapan. Sejauh manakah konsep belajar dalam bermain diterapkan pada materi calistung.

\section{KAJIAN PUSTAKA}

\section{Membaca dan Menulis}

Pengenalan membaca anak dapat dilakukan dengan berbagai cara salah satunya dilakukan pembagian kata, anak diperkenalkan dan diajarkan bunyi huruf dan menyusunnya, serta diperkenalkan dengan abjad satu persatu kemudian menghafalkan bunyinya. Anak diperkenalkan dengan penanggalan suku kata, kemudian dirangkai menjadi satu kata. Anak usia dini mulai mengenal hubungan antara tulisan, bunyi, dan artinya sehingga anak mengerti fungsi tulisan atau bacaanya.

Kemahiran membaca dan menulis seseorang sangat ditentukan oleh kemampuannya saat belajar membaca dan menulis permulaan. Purwanto, dkk (1997:10) menjelaskan bahwa pelajaran membaca dan menulis permulaan mengajarkan: (i) pengenalan huruf dan rangkaiannya, seperti: suku kata, kata, dan kalimat; (ii) cara menulis huruf, suku kata, kata dan kalimat pendek dengan benar. Jadi pelajaran membaca dan menulis permulaan bertujuan untuk memberikan kemampuan mengenal huruf dan mengubahnya menjadi rangkaian bunyi yang bermakna serta melancarkan teknik membaca pada anak-anak. Pelajaran membaca dan menulis permulaan biasanya dimulai tanpa menggunakan buku pelajaran karena mereka belum dapat membaca. 
Walaupun pelajaran membaca dan menulis permulaan tidak dimulai dengan menggunakan buku tetapi tetap menggunakan tulisan.

Ada beberapa alasan mengapa pelajaran membaca permulaan menggunakan tulisan. Ross, dkk (2009:30) menyebutkan beberapa alasan membaca permulaan menggunakan tulisan, alasan pertama adalah pengenalan tulisan sejak awal dapat membuat anak memiliki pengalaman membaca yang baik dan memberikan pengaruh sikap yang baik dalam membaca. Kedua, anak dapat mulai menyadari bahwa tulisan merupakan rekaman bunyi yang teratur. Alasan ketiga, bagi pembaca pemula, kata-kata lebih mempunyai arti daripada dihafalkan.

Mengajar membaca dan menulis permulaan, seorang guru harus hatihati menyampaikan materi maupun melakukan perpindahan materi. Perpindahan materi dapat dilakukan jika siswa dirasa sudah mampu untuk mengikuti materi selanjutnya. Suatu materi yang belum dapat dikuasai oleh siswa harus diulang dengan cara yang lebih sederhana dan menyenangkan karena bila siswa merasa tertekan dikuatirkan siswa akan menjadi bosan lalu frustasi karena merasa bodoh dan akhirnya menjadi minder dan tidak suka belajar membaca dan menulis lagi. Jadi, mengajarkan membaca dan menulis permulaan (selanjutnya disingkat MMP) merupakan kemampuan awal yang harus dimiliki anak untuk dapat membuka cakrawala pengetahuan yang lebih luas.

Menurut Spodek dan Saracho (1994:175-183) mengatakan bahwa ada dua cara yang ditempuh pembaca dalam memperoleh makna cetak, yaitu (1) langsung, yakni menghubungkan ciri penanda visual dari tulisan dengan maknanya, dan (2) tidak langsung, yakni mengidentifikasi bunyi dalam kata dan menghubungkannya dengan makna. Cara pertama digunakan oleh pembaca lanjut dan cara kedua digunakan oleh pembaca permulaan. 
Membaca permulaan merupakan kemampuan membaca pada tahap keberwacanaan. Secara teknis, pada tahap keberwacanaan ini, anak-anak diharapkan dapat menemukan sendiri sistem kebahasaan bahasa Indonesia (selanjutnya disingkat BI) melalui proses pembelajaran bahasa yang dilakukan berdasarkan konteks. Tahap keberwacanaan ini merupakan tujuan pembelajaran di sekolah dasar (selanjutnya disingkat SD) kelas-kelas awal, yaitu kelas 1 dan 2. Combs (1996:15) memilah kegiatan membaca permulaan menjadi 3 tahap, yaitu tahap persiapan, tahap perkembangan, dan tahap transisi. Dalam tahap persiapan, anak mulai menyadari tentang fungsi barang cetak, konsep tentang cara kerja barang cetak, konsep tentang huruf, dan konsep tentang kata. Dalam tahap perkembangan, anak mulai memahami pola bahasa yang terdapat dalam barang cetak. Anak mulai belajar memasangkan satu kata dengan kata lain. Dalam tahap transisi, anak mulai mengubah kebiasaan membaca bersuara menjadi membaca dalam hati. Anak mulai dapat melakukan kegiatan membaca dengan santai.

Paquette, dkk (2007:165) mengatakan bahwa semakin dini anak dikenalkan dengan teks yang ada dalam buku maka anak semakin siap untuk membaca dan sadar terhadap cetakan (tulisan). Kemampuan membaca dan menulis pada anak sangat dipengaruhi oleh kemampuan anak untuk sadar akan phonemik. Kesadaran phonemik yaitu kemampuan untuk membedakan bunyi dalam bahasa. Kemampuan ini terbentuk pada kemampuan mendengarkan. Potensi anak untuk dapat membaca dan menulis juga dapat dideteksi sejak dini melalui tahapan kesadaran phonemik tersebut.

Kesadaran phonemik di Taman Kanak-kanak ditunjukkan dengan ciri yaitu peduli suara/hubungan simbol-simbol, dan dapat mencampur fonem dan membagi suku kata. Terkait dengan kesadaran phonemik tersebut maka pendidik harus mampu menciptakan kegiatan pembelajaran yang 
mengembangkan kemampuan anak untuk mengembangkan kesadaran phonemik. Perkembangan bahasa untuk anak taman kanak-kanak berdasarkan acuan standar pendidikan anak usia dini Nomor 58 tahun 2009 mengembangkan tiga aspek yaitu menerima bahasa, mengungkapkan bahasa, dan keaksaraan. Lingkup perkembangan menerima bahasa yaitu kemampuan berbahasa secara reseptif, terdiri dari pengembangan menyimak perkataan orang lain, mengerti dua perintah yang diberikan bersamaan, memahami cerita yang dibacakan, mengenal perbendaharaan kata mengenai kata sifat, mengerti beberapa perintah, mengulang kalimat yang lebih kompleks, dan memahami aturan dalam suatu permainan.

\section{Berhitung}

Berdasarkan Permendiknas nomor 58 Tahun 2009 tentang Standar Pendidikan Anak Usia Dini yang dapat ditingkatkan lewat permainan kubus bergambar adalah menyebut urutan bilangan 1-20, mengenal konsep lambang bilangan dengan benda-benda sampai 1-20, membuat urutan bilangan 1-20 dengan benda-benda, memasangkan lambang bilangan dengan benda-benda sampai 1-20, membedakan dan membuat 2 kumpulan benda yang sama jumlahnya dan tidak sama, lebih banyak lebih sedikit, meniru lambang bilangan dengan benda 1-20 serta menyebutkan hasil penambahan dan pengurangan 1-20 dengan benda untuk persiapan memasuki Sekolah Dasar. Faktor-faktor yang mempengaruhi permainan anak, akan mempengaruhi perkembangan anak dalam memahami berhitung awal ini, yaitu: kesehatan, inteligensi, jenis permainan, lingkungan, dan status ekonomi.

Tiga tahapan penguasaan berhitung menurut Sisdiknas (2007) diantaranya adalah: 
a. Penguasaan konsep adalah pemahaman dan pengertian tentang sesuatu dengan menggunakan benda dan peristiwa kongkrit, seperti pengenalan warna, bentuk dan menghitung bilangan.

b. Masa transisi adalah proses berfikir yang merupakan masa peralihan dari pemahaman kongkrit menuju pengenalan lambang yang abstrak, dimana benda kongkrit itu masih ada dan mulai dikenalkan bentuk lambangnya. Hal ini harus dilakukan guna secara bertahap sesuai dengan laju dan kecepatan kemampuan anak yang secara individual berbeda. Misalnya, ketika guru menjelaskan konsep satu dengan menggunakan benda (satu buah pensil), anak-anak dapat menyebutkan benda lain yang memiliki konsep sama, sekaligus mengenalkan bentuk lambang dari angka satu itu.

c. Lambang adalah merupakan visualisasi dari berbagai konsep, misalnya lambang 7 untuk menggambarkan konsep bilangan tujuh, merah untuk ruang, dan persegi empat untuk menggambarkan konsep bentuk. Anak belajar berhitung bukan dari mengerjakan LK (lembar kerja) tetapi dari berbagai aktivitas permainan.

\section{METODE PENELITIAN}

Penelitian ini dilakukan pada tahun 2016 menggunakan pendekatan kualitatif. Responden adalah guru di sentra persiapan yang terdiri dari dua guru. Pengumpulan data dilakukan dengan indepth - interview, observasi dan dokumen. Indepth -interview dilakukan sebanyak empat kali. Observasi dilakukan sebanyak 8 kali pertemuan. Sementara studi dokumen dilakukan dengan mengumpulkan informasi-informasi tertulis yang dibutuhkan dalam penelitian ini, seperti kurikulum, silabus, dan Rencana Pelaksanaan Pembelajaran Harian. 


\section{TEMUAN DAN PEMBAHASAN}

\section{Pendekatan Kelas Sentra dengan Model Moving class}

Berdasarkan penelitian yang telah dilakukan, RA Al- Azhar menerapkan kelas sentra untuk proses pembelajarannya. Kelas sentra atau yang dikenal dengan istilah BCCT (Beyond Centre and Circle Time) merupakan pendekatan pembelajaran melalui sentra dan lingkaran. BCCT ini diadopsi dari Creative for Chilhood Research and Training (CCCRT) yang telah dipraktekkan 33 tahun lalu di Florida, Amerika Serikat. Rindaningsih (2009) subyek pembelajaran BCCT adalah anak sehingga anak dapat mengembangkan kemampuan sesuai dengan potensi yang dimilikinya, semua pembelajaran dilakukan sambil bermain.

Masing-masing kelas sentra memiliki aktivitas dan tujuan pembelajaran yang berbeda. Kelas sentra menyediakan fasilitas dan bahan belajar yang memiliki kekhasan masing-masing sesuai dengan tujuannya. Kelas sentra mendesain pembelajaran yang merangsang keaktifan siswa. Hal ini sesuai dengan yang dikatakan Herawati (2005:25) BCCT memfokuskan kegiatan anak pada sentra-sentra dan dikondisikan untuk mengembangkan atau membangun domain perkembangan anak seperti afektif, kognitif, psikomotor, bahasa dan keterampilan sosial. Dalam BCCT anak bermain aktif, kreatif dan berani mengambil keputusan.

Pendekatan kelas sentra yang dilaksanakan RA Al-Azhar ini mengharuskan murid berpindah kelas (moving clas) dari satu sentra ke sentra lainnya. Murid mendapatkan pengalaman belajar yang berbeda dan khas setiap berpindah kelas. Seperti yang diungkapakan Sagala (2011:183) moving class suatu model pembelajaran yang diciptakan untuk belajar aktif dan kreatif dengan sistem belajar mengajar bercirikan peserta didik yang mendatangi 
guru di kelas, bukan sebaliknya. Hal ini disebabkan setiap sentra menyediakan layanan belajar yang unik dan kesan masing-masing.

Pengalaman dan kesan belajar yang didapat murid akan bergantung pada bagaimana guru sentra menyajikan layanan pembelajaran. Keberhasilan kelas sentra dipengaruhi oleh guru sentra yang mengelola masing-masing sentra. Sejalan dengan yang diungkapkan Eddy (2012:23) guru sentra bukan menjadi center atau pusat ilmu pengetahuan sedang anak hanya menjadi pendengar dan pemerhati apa yang disampaikan oleh guru. Tapi guru sentra lebih berperan sebagai seorang observer dan motivator sehingga anak lebih aktif menjelajah, bereksplorasi dan menemukan sendiri pengalaman belajarnya.

RA Al-Azhar mendesain seluruh aktivitas dan materi pembelajaran dalam bentuk permainan. Murid dituntut mampu menyesuaikan diri dengan lingkungan belajar yang didatanginya. Kondisi ini melahirkan keaktifan dan kreativitas anak dalam mengikuti pembelajaran seperti yang disebutkan Sriyono (1992:8) pelaksanaan sistem moving class ini membutuhkan keaktifan siswa untuk belajar, keaktifan siswa akan terlihat secara intelektual dan emosional sehingga ia betul-betul berperan dan berpartisipasi dalam melakukan kegiatan belajar.

\section{Pembelajaran Membaca, Menulis, dan Berhitung.}

Seperti yang sudah disebutkan pada bagian sebelumnya, RA ALAzhar menerapkan kelas sentra pada proses pembelajarannya. Pembelajaran membaca, menulis, dan berhitung (calistung) dilakukan pada sentra persiapan. Adapun proses pembelajarannya akan diuraikan sebagai berikut:

\subsection{Membaca dan Menulis}


Pembelajaran membaca dimulai dengan strategi pengenalan huruf dan angka terlebih dahulu. Proses pengenalan huruf dan angka dilakukan dengan menggunakan media lagu. Deretan angka dan huruf dilagukan secara bersama-sama. Dari pengamatan yang dilakukan penggunaan media menjadi salah satu hal terpenting dalam proses pembelajaran. Salah satunya, penggunaan lagu. Murid sangat tertarik bagi dengan lagu-lagu yang disampaikan. Di dalam lagu tersimpan materi yang hendak diajarkan.

Dalam mengenalkan huruf, guru menggunakan media kartu berwarna warni. Kartu berwarna warni ditempelkan di papan tulis. Kemudian secara bersama sama guru dan murid menyanyikan lagu alphabetA, b, c, d, e, f, g, h, i, j, k, l, m, n, o, p, q, r, s, t, u, v, w, x, y, dan z.

Setelah bersama-sama menyanyikan lagu, tahap selanjutnya guru menunjuk huruf yang dinyanyikan tadi. Murid merespon dengan menjawab huruf yang ditunjuk guru. Setelah itu, dengan menunjuk sebuah huruf, guru bertanya ke beberapa murid. Dari hasil pengamatan terlihat murid yang mendapatkan les tambahan di luar jam sekolah sudah mengenal huruf dengan baik. Sementara, murid yang tidak mengikuti les masih terlihat kebingungan menjawab pertanyaan guru.

Di kesempatan lain, guru membuka majalah yang di dalamnya terdapat gambar benda-benda yang sudah dikenal baik oleh murid. Pada kesempatan ini, guru menunjuk sebuah gambar baju. Setelah semua murid melihat gambar tersebut, mereka diminta menyebutkan benda tersebut. Berikutnya, guru meminta murid huruf apa sajakah yang digunakan untuk membentuk kata baju. Guru menyuruh murid menunjuk huruf yang akan digunakan untuk menyusun kata baju diambil dari deretan alpabet yang disusun di papan tulis. Beberapa murid mulai menyebutkan huruf, kemudian guru menuliskan huruf yang disebutkan murid tadi. Namun, guru tidak 
menuliskannya secara langsung melainkan bertanya kepada murid bagaimana cara menulis huruf yang dimaksud mereka. Pada proses ini, murid yang memiliki pengetahuan awal tentang huruf juga masih mendominasi proses pembelajaran.

Pembelajaran membaca juga disajikan dengan menggunakan kartu acak. Kartu yang telah berisi alpabet dari A-Z diacak di dalam sebuah kotak. Kemudian, guru menuliskan sebuah kata di papan tulis. T-O-P-I. Selanjutnya, murid diminta mencari kartu apa saja yang dapat menyusun kata tersebut.

Hal yang sama juga terjadi pada proses membaca huruf hijaiyah. Guru membacakan deretan huruf hijaiyah.

ابت ث ج ح خد ذر زس ش صض طظع غ ف ق كل منه و وءي

Kemudian guru menempelkan kertas yang berisi huruf hijaiyah di papan tulis. Guru meminta murid membaca deretan huruf hijaiyah tersebut. Selanjutnya, secara acak guru menunjuk satu huruf kemudian guru meminta murid menyebut huruf apa yang yang sedang ditunjuk oleh guru. Dari pengamatan yang dilakukan, sama seperti pengenalan huruf alpabet, murid yang memiliki jam tambahan mengaji di rumah lebih menguasai konsep huruf hijaiyah ini.

Variasi pembelajaran menulis disajikan dengan beberapa cara, di antaranya sebagai berikut:

(a). Merangkai huruf

Dalam kegiatan merangkai huruf, guru menggunakan alat bantu buku cetak yang di dalamnya terdapat pola huruf dalam bentuk garis putus-putus. Murid diminta merangkai garis putus-putus tersebut agar membentuk kesatuan huruf secara utuh. Kegiatan ini akan memberikan efek semakin 
mahirnya anak dalam menuliskan sebuah huruf. Keterampilan motorik halus anak juga terasah melalui kegiatan ini.

(b). Meniru huruf

Dua tahap sebelumnya dianggap sebagai latihan awal bagi murid untuk melatih keterampilan menulisnya. Setelah naak berhasil pada tahap mencetak dna merangkai huruf anak dapat diberikan pelajaran meniru huruf yang dituliskan guru di papan tulis. Guru menuliskan beberapa huruf di papan tulis kemudian anak meniru di buku tulisnya masing-masing. Tahap meniru huruf ini akan sangat bergantung pada tahap sebelumnya.

Untuk mencapai keberhasilan dalam keterampilan menulis ini, murid sangat bergantung pada keterampilan membaca. Jika murid telah berhasil mengidentifikasi alpabet, maka murid akan lebih mudah menuliskan alpabaet tersebut. Biasanya guru akan melibatkan benda-benda di sekitar untuk memmbangkitkan imajinasi murid terhadap bentuk huruf tersebut. Misalnya huruf /i/. Huruf /i/ seolah-olah diwakilkan oleh bentuk tiang bendera. Huruf /o/ dimisalkan dengan bentuk bola, dan lainnya

Aktivitas selanjutnya ialah menuliskan alpabet dari A-Z, nama murid, dan benda-benda sederhana yang ada di sekitar murid. Biasanya, dalam menulis tahap awal bentuk huruf yang ditulis murid belumlah sempurna. Namun sudah dapat diidentifikasi huruf apa sebenarnya yang ingin ditulisnya. Sesuai dengan Comb (2005:15) pada tahap menulis awal ketika murid sudah mampu menuliskan alpabet dari A sampai $Z$ dan mampu menuliskan namanya sendiri maka pembelajaran menulis sudah dianggap berhasil.

Dalam menulis huruf hijaiyah, tahap awal guru bertanya dengan murid tentang bentuk huruf yang kaan ditulisnya. Misalnya saja huruf /a/ $11 /$ 
"anak umi, huruf /1/ bagaimana ya bentuknya?"

Dari pertanyaan umi guru ini, anak akan memberikan banyak variasi jawaban, diantaranya ialah

"lurus mi"

"kayak tiang listrik mi"

"gagang sapu mi"

Kemudian, guru berusaha menuliskan konsep huruf $/ /$ tersebut di papan tulis. Hal yang sama juga terjadi pada huruf lainnya. Guru berusaha menuliskan huruf berdasarkan konsep yang diberikan murid. Pembelajaran membaca dilaksanakan secara bertahap dimulai dengan proses pengenalan huruf, kemudian dilanjutkan dengan tahap lebih kompleks yaitu membaca rangkaian huruf menjadi kata sederhana yang akrab dengan kehidupan murid. Hal ini sesuai dengan yang dijelaskan Cochrane Efal dalam Dhieni (20055-9) membaca pada anak akan mengalami tahapan, tahap fantasi, tahap pembentukan konsep diri, tahap membaca gambar, tahap pengenalan bacaan, dan tahap lancar membaca.

Proses pengenalan huruf pada pembelajaran membaca dilakukan dengan banyak cara, di antaranya dengan penggunaan media lagu, media kartu, dan majalah. Begitu juga dengan pembelajaran membaca tingkat lanjut, aktivitas pembelajaran dilakukan dengan bantuan media majalah yang berisi gambar dan tulisan benda-benda yang terdapat di sekeliling siswa. Keberhasilan pembelajaran membaca dipengaruhi oleh media pembelajaran yang digunakan guru. Briggs dalam Rusdi Susilana (2009:6) mengatakan bahwa media menjadi alat untuk memberikan perangsang bagi siswa supaya terjadi proses belajar. Semakin menarik hati para murid media yang digunakan akan semakin terlaksana dengan baik proses pembelajarannya. 
Kemampuan menulis sangat dipengaruhi oleh keterampilan membaca. Membaca memegang peranan penting pada kemampuan menulis murid. Konsep mengenai huruf dan angka didapat dari proses membaca. Membaca merupakan kegiatan memindahkan gagasan ke dalam pikiran. Semakin mahir murid membaca akan memberikan efek pada kemampuan menulisnya. Seperti yang diungkapkan Semi (2007:16) menulis merupakan suatu proses kreatif memindahkan gagasan ke dalam lambang-lambang tulisan.

Pembelajaran menulis yang dilaksanakan di RA Al-Azhar juga dilakukan secara bertahap. Dimulai dari tahap merangkai huruf yang telah ditulis dengan garis putus-putus, menebalkan huruf, hingga menulis tingkat lanjutan berupa menulis kata-kata sederhana. Dimulai dari anak menarik garis, berlatih huruf, menulis namanya sendiri, serta menulis kata-kata sederhana yang berada di sekelilingnya. Hal ini sesuai dengan pendapat Comb (1996:15) pada tahap menulis awal ketika murid sudah mampu menuliskan alpabet dari A sampai $\mathrm{Z}$ dan mampu menuliskan namanya sendiri maka pembelajaran menulis sudah dianggap berhasil.

\subsection{Berhitung}

(a). Pengenalan angka

Pembelajaran berhitumg pada RA AL-Azhar diawali dengan pengenalan angka. Proses pengenalan angka dimulai dari angka 1-20. Aktivitas ini dimulai dengan menyebutkan deretan angka tersebut. Guru bersama-sama dengan murid menyebutkan angka 1 - 20 dengan menggunakan bahasa Indonesia, bahasa Inggris, dan bahasa Aceh.

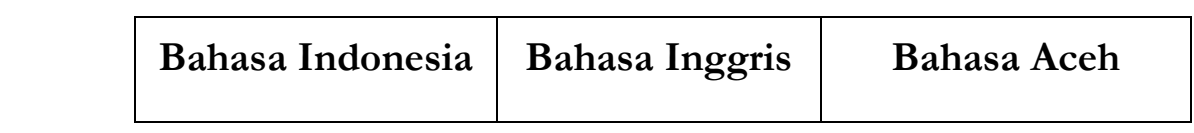


Journal of Linguistics, Literature \& Language Teaching

\begin{tabular}{|c|c|c|}
\hline Satu & One & Sa \\
\hline Dua & Two & Dua \\
\hline Tiga & Three & Lhee \\
\hline Empat & Four & Peut \\
\hline Lima & Five & Limong \\
\hline Enam & Six & Enam \\
\hline Tujuh & Seven & Tujoh \\
\hline Delapan & Eight & Lapan \\
\hline Sembilan & Nine & Sikuereng \\
\hline Sepuluh & Ten & Siploh \\
\hline Sebelas & Eleven & Siblah \\
\hline Dua belas & Twelve & Dua blah \\
\hline Tiga belas & Threeteen & Lhee blah \\
\hline Empat belas & Fourteen & Peut blah \\
\hline Lima belas & Fiveteen & Limong blah \\
\hline Enam belas & Sixteen & Enam blah \\
\hline Tujuh belas & Seventeen & Tujoh blah \\
\hline Delapan belas & Eighteen & Lapan blah \\
\hline Sembilan belas & Nineteen & Sikuereng blah \\
\hline Dua puluh & Twenty & Dua ploh \\
\hline
\end{tabular}

Pada proses pembelajaran berhitung tahap awal ini murid tidak terlalu sulit menyebutkan angka 1 - 20 dalam bahasa Indonesia, namun menyebut angka dalam bahasa Inggris dan bahasa Aceh beberapa murid mengalami kesulitan.

Berikutnya, guru menyebutkan deretan angka tersebut sambil menunjuk ke kartu angka 1 -20 yang berwarna warni yang ditempel di papan 
tulis. Kemudian, secara acak, guru meminta beberapa murid menyebutkan angka berapa yang ditunjuk oleh guru. Pada tahap ini terlihat beberapa murid kesulitan mengidentifikasi bentuk angka yang ditunjuk oleh guru. Hal ini terjadi karena murid hanya sebatas menghafal deretan angka tersebut tanpa memahami konsep bentuk angkanya.

Aktivitas lain yang dilakukan dalam proses pengenalan angka adalah dengan menggunakan media lagu. Penggunaan lagu dilakukn untuk menambah konsep angka murid. Salah satu lagunya adalah lagu angka nol, dengan syair sebagai berikut:

10 nolnya ada satu

100 nolnya ada dua

1000 nolnya ada tiga

1000000 nolnya ada enam

Panjang sekali seperti kereta api

10 nolnya ada berapa?

Satu

100 nolnya ada berapa?

Dua

1000 nolmya ada berapa?

Tiga

1000000 nolmya ada berapa?

Enam

Panjang sekali seperti kereta api

Bait awal syair lagu di atas mengenalkan angka 10, 100, 1000, dan sejuta kepada murid. Murid dengan guru bersama-sama bernyanyi. Pada bait 
kedua, guru bertanya kemudian murid yang menjawab berapa jumlah nol dari tiap angka yang ditanyakan. Bagi murid yang sudah berulang kali mendengarkan lagu ini, tentu jawaban akan berdasarkan hafalan. Selain itu jumlah nol yang ditanyakan akan membentuk konsep angka pada ingatan siswa.

Menghitung jumlah anggota tubuh dengan angka juga menjadi salah satu aktifitas lain yang dilakukan dalam mengenalkan angka pada siswa. siswa diminta menghubungkan jumlah anggota tubuh dengan konsep angka.

(b). Operasi Perhitungan

Dalam aktivitas pembelajaran berhitung, guru menggunakan alat bantu berupa gambar apel, kelereng, pensil dan alat bantu lainnya. Proses perhitungan didesain dengan aturan penjumlahan tidak lebih dari angka 20. Hal ini sangat penting dilakukan mengingat pada tahap pengenalan angka, murid hanya dikenalkan hanya sampai angka 20. Guru akan mensimulasikan proses penjumlahan. Dengan meletakkan 3 buah kelereng, kemudian bertanya kepada siswa jadi berapakah jumlah kelereng jika seorang murid memberikan 2 buah kelereng lagi. Secara bersama-sama murid menghitung jumlah kelereng yang sudah diterima oleh guru.

Kegiatan lain yang dilakukan dalam pembelajaran berhitung guru menuliskan gambar di buku tulis siswa kemudian siswa diminta menjawab berapa jumlah gambar yang ditulis guru. Penggunaan majalah yang di dalamnya juga terdapat laihan operasi perhitungan juga dilakukan untuk mengembangkan pengetahuan murid. Proses perhitungan pada tahap ini masih menggunakan gambar untuk membantu anak memahami konsep berhitung. Satu hal yang harus dipahami bahwa konsep perhitungan ini dibatasi dengan rentang angka 1-20 saja. 
Pada tahap operasi perhitungan juga dilakukan dengan bantuan benda-benda sederhana. Penggunaan majalah sebagai bahan belajar juga digunakan dalam tahap ini. Aktivitas berhitung dirancang dalam permainan. Sejalan dengan yang diungkapkan Siti Fauziah (2011) bahwa ketika anak belajar berhitung bukan dari mengerjakan LK (lembar kerja) tetapi dari berbagai aktivitas permainan akan meningkatkan hasil belajar.

Dengan demikian, proses pembelajaran di RA Al-Azhar dilakukan dengan strategi permainan dalam belajar. Hal ini dilakukan mengingat usia anak 4-6 tahun adalah fase bermain. Pembelajaran anak usia dini menggunakan esensi bermain. Esensi bermain meliputi perasaan senang, demokratis, aktif, tidak terpaksa dan merdeka. Sesuai dengan yang dijelaskan Suyanto (2005:9) bahwa pembelajaran hendaknya disusun sedemikian rupa sehingga menyenangkan, membuat anak tertarik untuk ikut serta dan tidak terpaksa. Oleh karena itu, pihak sekolah berupaya menciptakan iklim belajar yang sehat dan terus berbenah agar seluruh tujuan dari pelaksanaan pembelajaran pada setiap sentra dapat terlaksana dengan baik.

\section{SIMPULAN DAN SARAN}

RA Al- Azhar menerapkan kelas sentra untuk proses pembelajarannya. Kelas sentra atau yang dikenal dengan istilah BCCT (Beyond Centre and Circle Time) merupakan pendekatan pembelajaran melalui sentra dan lingkaran. RA Al-Azhar menyediakan delapan kelas sentra, yaitu sentra seni, olah tubuh, eksplorasi, imajinasi, balok, ibadah, tahfidz, dan sentra persiapan. Pendekatan kelas sentra yang dilaksanakan RA Al-Azhar ini mengharuskan murid berpindah kelas (moving class) dari satu sentra ke sentra lainnya. Murid mendapatkan pengalaman belajar yang berbeda dan khas setiap berpindah kelas. Pembelajaran membaca dilaksanakan secara bertahap 
dimulai dengan proses pengenalan huruf, kemudian dilanjutkan dengan tahap lebih kompleks yaitu membaca rangkaian huruf menjadi kata sederhana yang akrab dengan kehidupan murid.

Pembelajaran menulis yang dilaksanakan pada RA Al-Azhar juga dilakukan secara bertahap. Dimulai dari tahap merangkai huruf yang telah ditulis dengan garis putus-putus, menebalkan huruf, hingga menulis tingkat lanjutan berupa menulis kata-kata sederhana. Begitu juga pembelajaran berhitung dilakukan secara bertahap. Dimulai dari pengenalan angka, pemahaman konsep dituangkan ke dalam penulisan lambang angka, kemudian pada tahap lebih lanjut anak dikenalkan dengan operasi berhitung. Seluruh aktivitas pembelajaran dilakukan dengan bantuan alat dan media yang dapat meningkatkan minat dan kreativitas siswa. Selain itu, aktivitas pembelajaran disajikan dalam bentuk permainan.

Mengingatpendekatansentradanlingkaranmerupakanbagianpentingdal am proses pembelajaran di usiadini, pengadopsian, pemodifikasian, pengadaptasiansertapenambahanterhadappendekataninimenjadibagianpenting yang perludipertimbangkanolehpara guru-guru usiadinidalam proses pembelajaran.

\section{DAFTAR PUSTAKA}

Finn,CE., Jr, JTE Cribb Jr, WJ Bennett. (1999). The Educated Child: A Parent Guide fromPreschool Through Eight Grade. New York: The Free Press.

Combs, Martha. (1996). Developing Competent Readers and Writers in the Primary Grades. Simon \& Schuster Academic

W, Eddy. (2012). Manajemen "Moving Class" Sebagai Pengorganisasian Sumber DayaPembelajaran.Disertasi: UniversitasNegeri Malang.

Rindaningsih, Ida. Pengembangan Model Manajemen Strategik Berbasis BCCT pada

PAUD, 
http://ojs.umsida.ac.id/index.php/pedagogia/article/view/42/48 diakses 20 Oktober 2016 pukul 20.00 WIB

Hasan, Maimunah. (2009).Pendidikan Anak Usia Dini. Yogyakarta: Diva Press.

Semi, M. Atar. (2007). Dasar-Dasar Keterampilan Menulis. Bandung: Angkasa.

Mursid. (2015). Pengembangan Pembelajaran PAUD. Bandung: PT REMAJA ROSDAKARYA.

Herawati, Nety.(2005). Buku Pendidik Anak Usia Dini. Jakarta: Quantum.

Dhieni, Nurbiana. (2005). Metode Pengembangan Bahasa, Jakarta: Universitas Terbuka.

Peraturan Menteri Pendidikan Republik Indonesia Nomor 58 tahun 2009

Paquette, Kelli R., Susan E. Fello, and Mary Renck Jalongo. (2007). The talking drawings strategy: Using primary children's illustrations and oral language to improve comprehension of expository text. Early childhood education journal 35(1).

Susilana, Rusdi dan Cepi Riyana. (2009).Media Pembelajaran: Hakikat, Pengembangan, Pemanfaatan, dan Penilaian. Bandung: PT Wacana Prima.

Sagala, Syaiful. (2011). Kemampuan Profesional Guru dan Tenaga Kependidikan, Bandung.: Alfabeta.

Nur, Siti Fauziah, $\quad$ http://ejournal.unesa.ac.id/index.php/paudteratai/article/view/651 diakses tanggal 2 April 2017pukul 17.00

Suyanto. (2005).Konsep Dasar Anak Usia Dini. Jakarta: Departemen Pendidikan Nasional.

Sriyono., dkk. (1992). Teknik Belajar dalam CBSA. Jakarta : PT. Rineka Cipta. 